\title{
Patient-centered care pathways: what does it mean? An integrative conceptual framework to meet the need of an international consensus: a qualitative systematic review protocol
}

Jean-Baptiste Gartner ${ }^{1,2,3}$, Kassim Said Abasse ${ }^{1,2,3,4}$, Ghita Ben Zagguou ${ }^{1}$, Frédéric Bergeron ${ }^{5}$, Paolo Landa $^{6}$, Célia Lemaire ${ }^{7}$, André Côté ${ }^{1,2,3,4,8}$.

\section{Author's Affiliation}

${ }^{1}$ Département de management, Faculté des sciences de l'administration, Université Laval, Québec, QC, Canada

${ }^{2}$ Centre de recherche en gestion des services de santé, Université Laval, Québec, QC, Canada.

${ }^{3}$ Centre de recherche du CHU de Québec, Université Laval, Québec, QC, Canada.

${ }^{4}$ VITAM, Centre de recherche en santé durable, Université Laval, Québec, QC, Canada.

${ }^{5}$ Bibliothèque-Direction des services-conseils, Université Laval, Québec, QC, Canada.

${ }^{6}$ Département d'opérations et systèmes de décision, Université Laval, Québec, QC, Canada.

${ }^{7}$ Université de Strasbourg, EM Strasbourg-Business School, HuManiS, Strasbourg, France.

${ }^{8}$ Centre de recherche du CISSS de Chaudière-Appalache, Québec, QC, Canada.

\section{*Corresponding Author}

Jean-Baptiste Gartner, Ph.D student,

Département de Management, Faculté des Sciences de l'Administration, Université Laval

Centre de Recherche en Gestion des Services de Santé, Université Laval,

Centre de recherche du CHU de Québec-Université Laval

Québec, QC, Canada, G1V 0A6.

E-mail address: jean-baptiste.gartner.1@ulaval.ca 


\section{ABSTRACT}

Background: Faced with increased expectations regarding the quality and safety of health care delivery systems, a number of stakeholders are increasingly looking for more qualitative and efficient ways to deliver care. This study is conducted to provide a clear definition of the patient-centered care pathway and its characteristics to meet the need for an international consensus.

Methods: This qualitative systematic review aims to perform a systematic synthesis of published evidence concerning (1) the definition of the patient trajectory, patient pathway or patient journey and (2) their characteristics. With a consulting librarian, a comprehensive and systematic search in three databases was conducted (PUBMED, Embase, ABI/Inform), from 1995 to 2020 without language criteria. Eligibility criteria guiding data selection will follow the PICo mnemonic criteria consisting of (1) Population : all types of patients managed by health care delivery systems for an acute or chronic condition regardless of age or condition, (2) Phenomena : studies that contribute to the definition and conceptualization of the concepts of care trajectory, care pathway and patient journey resulting in a theoretical and conceptual contribution, and (3) Context : health care providers include all providers of primary, secondary, tertiary, and quaternary care in any geographic area. Two reviewers will independently screen, select, extract data and make a critical assessment of the methodology used with the JBI Qualitative Assessment and Review Instrument (JBI QARI).

Discussion: This systematic review will provide much-needed knowledge regarding patient-centered pathways. The results will benefit clinicians, decision makers, and researchers by giving them a clear and integrated definition and understanding of the patient-centered care pathways and their characteristics to finally meet the need for an international consensus.

Systematic review registration number:

Keywords: Patient pathway, Patient trajectory, Patient journey, Patient-centered, Patient experience, Qualitative systematic review.

\section{REVIEW QUESTION}

What is the difference in terms of definition and characteristics between the concepts of care pathway, care trajectory and patient journey?

In light of these results, how can we redefine and characterize the patient-centered care pathway focused on the patient's needs and expectations to meet the need of an international consensus? 


\section{INTRODUCTION}

Providing health and wellness services from an efficiency, equity, and sustainability perspective may pose major challenges in the near future, given the advent of new technologies and the emergence of other disruptive changes ${ }^{1}$, including accountability for quality delivery and cost control. Indeed, in its book "Crossing the Quality Chasm: A New Health System for the 21st Century,"2 the U.S. Institute of Medicine (IOM) highlighted in 2001 the problem of poor quality in health care delivery systems and issued an urgent call for fundamental changes in the organization and delivery of health care. This analysis of a "quality chasm" was based on four findings: the increasing complexity of science and technology, the rise of chronic disease, a poorly organized health care system, and constraints in harnessing the information technology revolution. Twenty years later, these challenges are still pervasive. The existence of key problems in the approach to quality delivery persist ${ }^{3}$. These problems are related as much to the significant fragmentation of organizations $s^{2,4,5}$, as they are between business units within clinical organizations themselves ${ }^{4}$. This results in siloed work with each provider entity responsible for only a portion of the overall quality and complete patient experience of care ${ }^{4}$. This operational reality is reflected in the approach of quality and performance management programs that focus primarily on the perspective and needs of healthcare professionals and organizations rather than on the needs and expectations of patients at the systemic level. This approach, focused on the perspective of professionals, leads to inconsistencies in patient care resulting in problems of quality and accessibility for the patient, as well as additional costs for society.

The systemic approach through a care pathway program seems to be a relevant solution. Proposed since the end of the 1990s, this approach has given rise to a significant amount of terminology. Thus, the terms integrated care pathway, care trajectory, patient journey, care continuum have been used even though they often cover identical realities ${ }^{6}$. Moreover, this approach has given rise to a very large number of definitions, up to 37 definitions being found ${ }^{7}$. Given this plurality of definitions, the characteristics of patient-centered care pathways have also been subject to great variability ${ }^{7}$. The definition and characteristics of the trajectory varies from country to country and may include only one episode of care, focus only on the treatment phase, include only the post-diagnosis phase or encompass the entire patient journey. For example, in oncology, most pathways were limited to specific components of the cancer journey ${ }^{8}$. As a result, a systematic review of cost-effectiveness of colorectal cancer highlighted obvious discrepancies in the results of studies from different regions. They attribute these inconsistencies to several factors including the difference in the description of the trajectory and the variability in treatment phases used in the studies ${ }^{9}$. This variability results in an inability to conduct reliable comparative studies of care pathway programs at the international level. For this reason, in 2020 the WHO called the "ministries of health to design optimal care pathways, mapping patient's journey from first contact with the health system to completion of treatment and survivor care..." ${ }^{\prime 10}$. This definition is all the more necessary as certain barriers to the implementation of these programs have been removed. On the one hand, limited access to valid and reliable data from 
multiple organizations ${ }^{11}$ has been offset by massive investment of health systems in Electronic Medical Records which has provided structured and interconnectable data to examine the patient's trajectory through the system in an innovative way ${ }^{12}$. On the other hand, the main difficulties in highlighting the complexity of the referral trajectory ${ }^{13}$, frequently resulting from the mobilization of a Delphi method mobilizing the clinicians' perspective, have been overcome by proposing new methods such as machine learning or qualitative methods, these methods focusing on the real care trajectory and for the qualitative part on the patient's experience ${ }^{14,15,16}$ through their needs and expectations. That's why it is now time to define a standardized and internationally recognized integrative conceptual framework in order to meet the need for sharing knowledge internationally regarding the development, implementation and evaluation of pathways ${ }^{7}$.

A preliminary search for existing systematic reviews on the topic has been conducted in JBI Database of Systematic Reviews and Implementation Reports, Cochrane Database and PROSPERO. Patient pathways have already been the subject of few systematic reviews, but authors limited their search to use and outcomes for specific pathologies such as cancer in general ${ }^{17}$, breast cancer ${ }^{18}$, blunt thoracic injury ${ }^{19}$, cardiovascular disease ${ }^{20}$, adolescent idiopathic scoliosis ${ }^{21}$ or for specific phases such as end of $\operatorname{life}^{22}$. To our knowledge, the only review that deals with the concept of care pathways in a whole-ofsystem approach and not focused on one pathology was made in $2006^{23}$, reviewed literature published within a short, 3-year time period and used only one bibliographic database (PubMed).

The patient-centered care pathway programs have recently demonstrated encouraging results in terms of reduced variation in care, improved accessibility, quality, sustainability, and cost-effectiveness of care $^{7}$. Furthermore, the evolution of knowledge and information technology and the investment of health systems in data-sharing infrastructures, as well as a definition of the levers of patient engagement, make it possible to define a powerful model for improving care trajectories. Therefore, our systematic review of the literature aims to answer the following research questions: What is the difference in terms of definition and characteristics between a care pathway, a care trajectory and a patient journey? In light of these results, how can we redefine and characterize the patient-centered care pathway focused on the patient's needs and expectations to meet the need of an international consensus?

\section{REVIEW QUESTIONS}

What is the difference in terms of definition and characteristics between a care pathway, a care trajectory and a patient journey?

In light of these results, how can we redefine and characterize the patient-centered care pathway focused on the patient's needs and expectations to meet the need of an international consensus?

\section{INCLUSION CRITERIA}

As recommended by JBI Reviewer's Manual ${ }^{24}$, this review follows the PICo mnemonic criteria ${ }^{25}$ consisting in defining both the Population, the Phenomena of Interest and the Context.

\section{Population}


This review considers qualitative studies and conceptual articles that include or focus on all types of patients managed by health care delivery systems for an acute or chronic condition regardless of age or condition.

\section{Phenomena of interest}

This review focuses on studies that contribute to the definition and conceptualization of the concepts of patient trajectory, patient pathway or patient journey resulting in a theoretical and conceptual contribution. Thus, on the one hand, qualitative studies involving a single episode of care limited in time (a one-time treatment) or space (a single hospital service/department) were excluded to the extent that the care trajectory involves multiple points of interaction over time ${ }^{26,27}$ and multiple organizational structures or intra-organizational entities along the care continuum ${ }^{28}$. On the other hand, studies with no theoretical or conceptual input were also excluded.

\section{Context}

The context studied is composed of health care providers in any geographic area. Health care providers include all providers of primary, secondary, tertiary, and quaternary care ${ }^{28}$. These providers can be both health care organizations (general practice clinics, hospitals, intensive care units, emergency departments, long-term care facilities, etc.) and individual providers (physicians, nurses, administrators, pharmacists, etc.).

\section{Types of studies}

This review considers conceptual articles or qualitative studies that focus on qualitative data including, but not limited to, designs such as phenomenology, grounded theory, ethnography, and action research. Descriptive qualitative studies that describe the experience or describe the effects of the experience were also considered. Mixed-methods studies were considered only if data from the qualitative components could be clearly extracted. Our search focused on peer-reviewed scientific articles. Therefore, books, doctoral or master's theses, and abstracts from conference presentations were excluded due to time and resource limitations. No language limits were applied. Finally, the study period was limited to the years 1995 to 2020, as the concept of the care pathway program was implemented in the second half of the $1990 \mathrm{~s}^{6}$ and in line with the objective of achieving a current redefinition and characterization of the patient-centered care pathway.

\section{SEARCH STRATEGY}

The search strategy was developed in collaboration with a consulting librarian and aims to find published peer-reviewed studies. An initial limited search of MEDLINE and CINAHL has been undertaken followed by analysis of the text words contained in the title and abstract, and of the index terms used to describe the article. This informed the development of a search strategy which was tailored for each information source. The full search strategy in PUBMED, Embase and ABI/Inform are detailed in Appendix 1. The interrogation of the three databases resulted in 15281 studies. These studies were imported into the Covidence ${ }^{\circledR}$ software and 209 duplicates were automatically deleted. The reference list of all studies selected for critical appraisal will be screened for additional studies. 


\section{ASSESSMENT OF METHODOLOGICAL QUALITY}

Following the standardized critical appraisal instruments from the JBI Qualitative Assessment and Review Instrument (JBI QARI) ${ }^{24}$, eligible studies will be assessed by two independent reviewers for methodological validity prior to inclusion in the review. Authors of papers will be contacted to request missing or additional data for clarification, where required. Any disagreements that arise between the reviewers will be resolved through discussion, or with a third reviewer. The results of critical appraisal will be reported in narrative form, regardless of studies methodological quality, and data extraction and synthesis will be summarized in a Table.

\section{DATA EXTRACTION}

Qualitative data will be extracted from papers included in the review using the standardized data extraction tool from JBI SUMARI by two independent reviewers. The data extracted will include specific details about the populations, context, culture, geographical location, study methods and the phenomena of interest relevant to the review question and specific objectives. Findings, and their illustrations, will be extracted and assigned a level of credibility.

\section{DATA SYNTHESIS}

Qualitative research findings will, where possible be pooled using JBI SUMARI with the meta aggregation approach. This will involve the aggregation or synthesis of findings to generate a set of statements that represent that aggregation, through assembling the findings and categorizing these findings on the basis of similarity in meaning. These categories are then subjected to a synthesis in order to produce a single comprehensive set of synthesized findings that can be used as a basis for evidence based practice. Where textual pooling is not possible the findings will be presented in narrative form.

\section{CONFLICTS OF INTEREST}

The authors declare no conflict of interest

\section{ACKNOWLEDGEMENTS}

This qualitative systematic review is part of a $\mathrm{PhD}$ project (JBG).

\section{References}

1. Horizons Canada (2018). Horizon de politiques Canada : La prochaine génération d'enjeux mondiaux émergents. https://horizons.gc.ca/fr/2018/10/19/la-prochainegeneration-denjeux-mondiaux-emergents/\#la-sante

2. Institute of Medicine America (2001). Crossing the quality chasm : a new health system for the 21st century. National Academy Press.

3. Ocloo, J., Goodrich, J., Tanaka, H., Birchall-Searle, J., Dawson, D., \& Farr, M. (2020). The importance of power, context and agency in improving patient experience through a patient and family centred care approach. Health Research Policy and Systems, 18(1).

4. Kaplan, R. S., \& Witkowski, M. L. (2014). Better accounting transforms health care delivery. Accounting Horizons, 28(2), 365-383.

5. Louis, C. J., Clark, J. R., Gray, B., Brannon, D., \& Parker, V. (2017). Service line structure and decision-maker attention in three health systems: Implications for patient-centered care. Health Care Management Review, 44(1). 
6. Lamb, G. S. (1997). Outcomes Across the Care Continuum. MEDICAL CARE PHILADELPHIA-, 35(11 SUPP/1), NS106-NS117.

7. Bergin, R. J., Whitfield, K., White, V., Milne, R. L., Emery, J. D., Boltong, A., Hill, D., Mitchell, P., Roder, D., Walpole, E., Marvelde, L., \& Thomas, R. J. S. (2020). Optimal care pathways: A national policy to improve quality of cancer care and address inequalities in cancer outcomes. Journal of cancer policy, 25.

8. Khan A.I., Arthurs E., Gradin S., MacKinnon M., Sussman J., Kukreti V. (2017). Integrated care planning for Cancer patients: a scoping review, Int. J. Integr. Care 17 (6) 5.)

9. Ran, T., Cheng, C. Y., Misselwitz, B., Brenner, H., Ubels, J., \& Schlander, M. (2019). Costeffectiveness of colorectal cancer screening strategies - a systematic review. Clinical Gastroenterology and Hepatology, 17(10), 1969-1981.

10. WHO Report on Cancer: Setting Priorities, Investing Wisely and Providing Care for All, World Health Organisation, 2020.

11. Solomon, R., Damba, C., \& Bryant, S. (2013). Measuring quality at a system level: an impossible task? The Toronto Central LHIN Experience. Healthcare quarterly (Toronto, Ont.), 16(4), 36-42.

12. Rayner, J., Khan, T., Chan, C., \& Wu, C. (2020). Illustrating the patient journey through the care continuum: Leveraging structured primary care electronic medical record (EMR) data in Ontario, Canada using chronic obstructive pulmonary disease as a case study. International Journal of Medical Informatics, 140, 104159.

13. Galvin, M., Madden, C., Maguire, S., Heverin, M., Vajda, A., Staines, A., \& Hardiman, O. (2015). Patient journey to a specialist amyotrophic lateral sclerosis multidisciplinary clinic: an exploratory study. BMC Health Services Research, 15, 571.

14. McCarthy, S., O’Raghallaigh, P., Woodworth, S., Lim, Y. L., Kenny, L. C., \& Adam, F. d. r. (2016). An integrated patient journey mapping tool for embedding quality in healthcare service reform. Journal of Decision Systems, 25(sup1), 354-368.

15. Burns, K. (2018). ISQUA18-2613Patients Measuring their Experiences with their Healthcare System: Targeting Improvement in Access, Quality, Safety and Patient and Family Centred Care Outcomes. International Journal for Quality in Health Care, 30(suppl_2), 22-23.

16. Nuti, S., De Rosis, S., Bonciani, M., \& Murante, A. M. (2018). Rethinking Healthcare Performance Evaluation Systems towards the People-Centredness Approach: Their Pathways, their Experience, their Evaluation. Healthcare Papers, 17(2), 56-64.

17. van Hoeve, J. C., Vernooij, R. W., Fiander, M., Nieboer, P., Siesling, S., \& Rotter, T. (2020). Effects of oncological care pathways in primary and secondary care on patient, professional and health systems outcomes: a systematic review and meta-analysis. Systematic reviews, 9(1), 1-15.

18. Joshi A., Sabesan S., Larkins S., Evans R., Brown A. Use and impact of care pathways in Breast Cancer : A systematic review of literature. PROSPERO 2020

19. Baker, M. E., Woolley, M. A., Xyrichis, A., Norton, C., Hopkins, P., \& Lee, G. (2020). How does the implementation of a patient pathway-based intervention in the acute care of blunt thoracic injury impact on patient outcomes? A systematic review of the literature. Injury.

20. Seguin, M. L., Rangnekar, A., Renedo, A., Palafox, B., McKee, M., \& Balabanova, D. (2020). Systematic review of frameworks used to conceptualise health pathways of individuals diagnosed with cardiovascular diseases. BMJ global health, 5(9), e002464.

21. Beauséjour, M., Goulet, L., Feldman, D. E., Da Silva, R. B., Pineault, R., Rossignol, M., ... \& Labelle, H. (2015). Pathways of healthcare utilisation in patients with suspected adolescent idiopathic scoliosis: a cross-sectional study. BMC health services research, $15(1), 1-12$.

22. Chan, R. J., Webster, J., \& Bowers, A. (2016). End-of-life care pathways for improving outcomes in caring for the dying. Cochrane Database of Systematic Reviews, (2).

23. De Bleser, L., Depreitere, R., WAELE, K. D., Vanhaecht, K., Vlayen, J., \& Sermeus, W. (2006). Defining pathways. Journal of nursing management, 14(7), 553- 563. 
24. Aromataris E, Munn Z. Chapter 1: JBI Systematic Reviews. In: Aromataris E, Munn Z (Editors). Joanna Briggs Institute Reviewer's Manual. The Joanna Briggs Institute, 2017.

25. Lockwood C, Porrit K, Munn Z, Rittenmeyer L, Salmond S, Bjerrum M, Loveday H, Carrier J, Stannard D. Chapter 2: Systematic reviews of qualitative evidence. In: Aromataris E, Munn Z (Editors). Joanna Briggs Institute Reviewer's Manual. The Joanna Briggs Institute, 2017.

26. Ponsignon, F., Smart, A., \& Phillips, L. (2018). A customer journey perspective on service delivery system design: insights from healthcare. International Journal of Quality and Reliability Management, 35(10), 2328-2347.

27. Cherif, E., Martin-Verdier, E., \& Rochette, C. (2020). Investigating the healthcare pathway through patients' experience and profiles: implications for breast cancer healthcare providers. BMC Health Services Research, 20(1), 1-11.

28. Kempa-Liehr, A. W., Lin, C. Y.-C., Britten, R., Armstrong, D., Wallace, J., Mordaunt, D., \& O'Sullivan, M. (2020). Healthcare pathway discovery and probabilistic machine learning. International Journal of Medical Informatics, 137. 
Appendix I: Search strategy

PubMed

Date of the search: 16-01-2021

Database limit: No database limit has been apply

\begin{tabular}{|c|c|c|c|}
\hline Concepts & $\#$ & Search strategy & Results \\
\hline $\begin{array}{l}\text { Healthcare } \\
\text { pathway } \\
\text { (Controlled } \\
\text { vocabulary) }\end{array}$ & 1 & $\begin{array}{l}\text { "Patient Care Management"[Mesh:NoExp] OR } \\
\text { "Workflow"[Mesh:NoExp] }\end{array}$ & 10,098 \\
\hline $\begin{array}{l}\text { Healthcare } \\
\text { pathway (Free } \\
\text { vocabulary) }\end{array}$ & 2 & $\begin{array}{l}\text { Healthcare pathway*[TIAB] OR Clinical Processes[TIAB] OR } \\
\text { medical processes[TIAB] OR healthcare processes[TIAB] OR } \\
\text { Patient Journey[TIAB] } \\
\text { OR processes model*[TIAB] OR workflow management[TIAB] }\end{array}$ & 2,309 \\
\hline $\begin{array}{l}\text { Healthcare } \\
\text { pathway } \\
\text { (Combined) }\end{array}$ & 3 & \#1 OR \#2 & 12,270 \\
\hline $\begin{array}{l}\text { Healthcare } \\
\text { access } \\
\text { (Controlled } \\
\text { vocabulary) }\end{array}$ & 4 & $\begin{array}{l}\text { "Health Services Accessibility"[Mesh:NoExp] OR "Health } \\
\text { Equity"[Mesh] OR "Waiting Lists"[Mesh:NoExp] OR "Time } \\
\text { Factors"[Mesh:NoExp] }\end{array}$ & $1,280,419$ \\
\hline $\begin{array}{l}\text { Healthcare } \\
\text { access (Free } \\
\text { vocabulary) }\end{array}$ & 5 & $\begin{array}{l}\text { Health Services Access*[TIAB] OR Health Care Access*[TIAB] OR } \\
\text { Health Services Availab*[TIAB] OR Access to Health Care[TIAB] OR } \\
\text { Health Equity[TIAB] OR Health inequit*[TIAB] OR Health } \\
\text { disparities[TIAB] OR Wait* times[TIAB] OR Waiting Lists[TIAB] }\end{array}$ & 38,478 \\
\hline $\begin{array}{l}\text { Healthcare } \\
\text { access } \\
\text { (combined) }\end{array}$ & 6 & \#4 OR \#5 & $1,307,321$ \\
\hline $\begin{array}{l}\text { Effectiveness } \\
\text { (Controlled } \\
\text { vocabulary) }\end{array}$ & 7 & $\begin{array}{l}\text { "Patient Satisfaction"[Mesh:NoExp] OR "Patient } \\
\text { Readmission"[Mesh] OR "Hospital Mortality"[Mesh] }\end{array}$ & 140,733 \\
\hline $\begin{array}{l}\text { Effectiveness } \\
\text { (Free vocabulary) }\end{array}$ & 8 & $\begin{array}{l}\text { Patient Satisfaction[TIAB] OR Patient needs[TIAB] OR Hospital } \\
\text { Readmissions[TIAB] OR Patient Readmission[TIAB] OR } 30 \text { Day } \\
\text { Readmission[TIAB] OR readmission rate[TIAB] OR Mortalit*[TIAB] } \\
\text { OR Death rate[TIAB] }\end{array}$ & 854,571 \\
\hline $\begin{array}{l}\text { Effectiveness } \\
\text { (combined) }\end{array}$ & 9 & \#7 OR \#8 & 936,302 \\
\hline $\begin{array}{l}\text { Efficiency as } \\
\text { productivity } \\
\text { (Controlled } \\
\text { vocabulary) }\end{array}$ & 10 & $\begin{array}{l}\text { "Operative Time"[Mesh] OR "Office Visits/statistics and numerical } \\
\text { data"[Mesh:NoExp] OR "Referral and Consultation/statistics and } \\
\text { numerical data"[Mesh:NoExp] OR "Bed Occupancy"[Mesh:NoExp] } \\
\text { OR "Time-to-Treatment"[Mesh] OR "Time } \\
\text { Management"[Mesh:NoExp] }\end{array}$ & 41,453 \\
\hline $\begin{array}{l}\text { Efficiency as } \\
\text { productivity } \\
\text { (Free vocabulary) }\end{array}$ & 11 & $\begin{array}{l}\text { Surgical Time*[TIAB] OR Operative Time*[TIAB] OR "Bed } \\
\text { Occupancy"[TIAB] } \\
\text { OR Treatment Delay*[TIAB] OR Time-to-Treatment*[TIAB] OR } \\
\text { Delayed Treatment*[TIAB] OR length of operation[TIAB] OR } \\
\text { length of surgery[TIAB] } \\
\text { operat* time }[T I A B] \text { OR surgery time[TIAB] OR surgery } \\
\text { duration[TIAB] OR patient referral[TIAB] OR therapy } \\
\text { Delay*[TIAB] }\end{array}$ & 38,259 \\
\hline $\begin{array}{l}\text { Efficiency as } \\
\text { productivity } \\
\text { (combined) }\end{array}$ & 12 & $\# 10$ OR \#11 & 72,736 \\
\hline
\end{tabular}




\begin{tabular}{|c|c|c|c|}
\hline $\begin{array}{l}\text { Efficiency as } \\
\text { economic } \\
\text { (Controlled } \\
\text { vocabulary) }\end{array}$ & 13 & $\begin{array}{l}\text { "Costs and Cost Analysis"[Mesh:NoExp] OR "Cost-Benefit } \\
\text { Analysis"[Mesh] OR "Health Care Costs"[Mesh] OR "Direct Service } \\
\text { Costs"[Mesh] OR "Cost Control"[Mesh] OR "Hospital } \\
\text { Costs"[Mesh] }\end{array}$ & 201,783 \\
\hline $\begin{array}{c}\text { Efficiency as } \\
\text { economic } \\
\text { (Free vocabulary) }\end{array}$ & 14 & Cost* $^{*}[\mathrm{TIAB}]$ & 640,920 \\
\hline $\begin{array}{l}\text { Efficiency as } \\
\text { economic } \\
\text { (combined) }\end{array}$ & 15 & $\# 13$ OR \#14 & 716,284 \\
\hline $\begin{array}{l}\text { Safety and } \\
\text { quality } \\
\text { (Controlled } \\
\text { vocabulary) }\end{array}$ & 16 & $\begin{array}{l}\text { "Quality Assurance, Health Care"[Mesh:NoExp] OR "Quality of } \\
\text { Health Care"[Mesh:NoExp] OR "Total Quality } \\
\text { Management"[Mesh:NoExp] OR "Quality Indicators, Health } \\
\text { Care"[Mesh:NoExp] OR "Efficiency, Organizational"[Mesh] OR } \\
\text { "Medical Errors"[Mesh:NoExp] OR "Medication } \\
\text { Errors"[Mesh:NoExp] OR "Accidents, Occupational"[Mesh] }\end{array}$ & 210,821 \\
\hline $\begin{array}{c}\text { Safety and } \\
\text { quality } \\
\text { (Free vocabulary) }\end{array}$ & 17 & $\begin{array}{l}\text { Quality of Healthcare[TIAB] OR Healthcare Quality[TIAB] OR } \\
\text { Continuous Quality Management[TIAB] OR Total Quality } \\
\text { Management[TIAB] OR Six Sigma*[TIAB] OR hospital } \\
\text { accidents[TIAB] OR medical error[TIAB] OR diagnostic error[TIAB] } \\
\text { OR medication error[TIAB] OR surgical error[TIAB] } \\
\text { OR therapeutic error[TIAB] }\end{array}$ & 10,963 \\
\hline $\begin{array}{l}\text { Safety and } \\
\text { quality } \\
\text { (combined) }\end{array}$ & 18 & \#16 OR \#17 & 216,480 \\
\hline $\begin{array}{l}\text { Characteristics of } \\
\text { Staff } \\
\text { (Controlled } \\
\text { vocabulary) }\end{array}$ & 19 & $\begin{array}{l}\text { "Job Satisfaction"[Mesh:NoExp] OR Personnel } \\
\text { Turnover[Mesh:NoExp] OR Personnel Loyalty[Mesh:NoExp] OR } \\
\text { "Workload"[Mesh] OR Absenteeism[Mesh:NoExp] OR } \\
\text { Presenteeism[Mesh:NoExp] OR "Shift Work Schedule"[Mesh] }\end{array}$ & 57,673 \\
\hline $\begin{array}{c}\text { Characteristics of } \\
\text { Staff } \\
\text { (Free vocabulary) }\end{array}$ & 20 & $\begin{array}{l}\text { Job satisfaction[TIAB] OR work satisfaction[TIAB] OR physician* } \\
\text { satisfaction[TIAB] OR nurs* satisfaction[TIAB] OR allied health* } \\
\text { satisfaction[TIAB] OR staff Loyalty[TIAB] OR staff turnover[TIAB] } \\
\text { OR staff rentention[TIAB] OR Personnel Turnover[TIAB] OR } \\
\text { Personnel rentention[TIAB] OR Personnel Loyalty[TIAB] OR } \\
\text { employee rentention[TIAB] OR employee turnover[TIAB] OR } \\
\text { employee Loyalty[TIAB] OR Absenteeism[TIAB] OR } \\
\text { Presenteeism[TIAB] OR Night Shift[TIAB] OR Rotating Shift[TIAB] } \\
\text { OR overtime[TIAB] OR workload[TIAB] }\end{array}$ & 80,766 \\
\hline $\begin{array}{c}\text { Characteristics of } \\
\text { Staff } \\
\text { (combined) }\end{array}$ & 21 & $\# 19$ OR \#20 & 120,061 \\
\hline $\begin{array}{l}\text { Combination of } \\
\text { concepts }\end{array}$ & 22 & \#3 AND (\#6 OR \#9 OR \#12 OR \#15 OR \#18 OR \#21) & 4,243 \\
\hline
\end{tabular}

Embase (Embase.com)

Date of the search: 16-01-2021

Database limit: Embase results only

\begin{tabular}{|c|c|l|c|}
\hline Concepts & $\#$ & Search strategy & Results \\
\hline $\begin{array}{c}\text { Healthcare } \\
\text { pathway } \\
\text { (Controlled } \\
\text { vocabulary) }\end{array}$ & 1 & $\begin{array}{l}\text { 'health care management'/de OR 'managed care } \\
\text { organization'/de }\end{array}$ & 31,359 \\
\hline
\end{tabular}




\begin{tabular}{|c|c|c|c|}
\hline $\begin{array}{l}\text { Healthcare } \\
\text { pathway (Free } \\
\text { vocabulary) }\end{array}$ & 2 & $\begin{array}{l}\text { "workflow management":ti,ab,kw OR "Healthcare } \\
\text { pathway\$":ti,ab,kw OR "Patient Journey":ti,ab,kw OR ((Clinical } \\
\text { OR medical OR Healthcare OR model*) NEAR/3 } \\
\text { processes):ti,ab,kw }\end{array}$ & 14,930 \\
\hline $\begin{array}{l}\text { Healthcare } \\
\text { pathway } \\
\text { (Combined) }\end{array}$ & 3 & \#1 OR \#2 & 46,157 \\
\hline $\begin{array}{l}\text { Healthcare } \\
\text { access } \\
\text { (Controlled } \\
\text { vocabulary) }\end{array}$ & 4 & $\begin{array}{l}\text { 'health care access'/de OR 'health equity'/de OR 'time factor'/de } \\
\text { OR 'hospital admission'/de }\end{array}$ & 307,606 \\
\hline $\begin{array}{l}\text { Healthcare } \\
\text { access (Free } \\
\text { vocabulary) }\end{array}$ & 5 & $\begin{array}{l}\text { (Health NEAR/2 (Access* OR Availab* OR Equity OR inequit* OR } \\
\text { disparities)):ti,ab,kw OR "Wait* times":ti,ab,kw OR "Waiting } \\
\text { Lists":ti,ab,kw }\end{array}$ & 67,971 \\
\hline $\begin{array}{l}\text { Healthcare } \\
\text { access } \\
\text { (combined) }\end{array}$ & 6 & \#4 OR \#5 & 360,685 \\
\hline $\begin{array}{l}\text { Effectiveness } \\
\text { (Controlled } \\
\text { vocabulary) }\end{array}$ & 7 & $\begin{array}{l}\text { 'patient satisfaction'/de OR 'hospital mortality'/de OR 'hospital } \\
\text { readmission'/de }\end{array}$ & 239,961 \\
\hline $\begin{array}{l}\text { Effectiveness } \\
\text { (Free vocabulary) }\end{array}$ & 8 & $\begin{array}{l}\text { (Patient NEAR/2 (satisfaction OR needs)):ti,ab,kw OR } \\
\text { Mortalit*:ti,ab,kw } \\
\text { OR "Death rate":ti,ab,kw OR ((Hospital OR Patient OR "30 Day" } \\
\text { OR rate) NEAR/2 readmission\$):ti,ab,kw }\end{array}$ & $1,268,791$ \\
\hline $\begin{array}{l}\text { Effectiveness } \\
\text { (combined) }\end{array}$ & 9 & \#7 OR \#8 & $1,395,359$ \\
\hline $\begin{array}{l}\text { Efficiency as } \\
\text { productivity } \\
\text { (Controlled } \\
\text { vocabulary) }\end{array}$ & 10 & $\begin{array}{l}\text { 'operation duration'/de OR 'hospital bed utilization'/de OR 'time } \\
\text { to treatment'/de OR 'time management'/de OR 'consultation'/de } \\
\text { OR 'patient referral'/de OR 'therapy delay'/de }\end{array}$ & 374,406 \\
\hline $\begin{array}{l}\text { Efficiency as } \\
\text { productivity } \\
\text { (Free vocabulary) }\end{array}$ & 11 & $\begin{array}{l}\text { ((operat* OR surgery OR surgical) NEAR/2 (time\$ OR duration OR } \\
\text { length)):ti,ab,kw OR "Bed Occupancy":ti,ab,kw OR "Time-to- } \\
\text { Treatment":ti,ab,kw OR "patient referral":ti,ab,kw OR } \\
\text { ((Treatment\$ OR therapy) NEAR/2 Delay*):ti,ab,kw }\end{array}$ & 211,150 \\
\hline $\begin{array}{l}\text { Efficiency as } \\
\text { productivity } \\
\text { (combined) }\end{array}$ & 12 & \#10 OR \#11 & 497,452 \\
\hline $\begin{array}{l}\text { Efficiency as } \\
\text { economic } \\
\text { (Controlled } \\
\text { vocabulary) }\end{array}$ & 13 & $\begin{array}{l}\text { 'cost'/de OR 'health care cost'/de OR 'hospital cost'/exp OR 'cost } \\
\text { control'/de OR 'cost benefit analysis'/de OR 'cost effectiveness } \\
\text { analysis'/de }\end{array}$ & 509,663 \\
\hline $\begin{array}{l}\text { Efficiency as } \\
\text { economic } \\
\text { (Free vocabulary) }\end{array}$ & 14 & Cost*:ti,ab,kw & 871,016 \\
\hline $\begin{array}{l}\text { Efficiency as } \\
\text { economic } \\
\text { (combined) }\end{array}$ & 15 & \#13 OR \#14 & $1,090,146$ \\
\hline $\begin{array}{l}\text { Safety and } \\
\text { quality } \\
\text { (Controlled } \\
\text { vocabulary) }\end{array}$ & 16 & $\begin{array}{l}\text { 'health care quality'/de OR 'medical error'/exp OR 'total quality } \\
\text { management'/de OR 'organization and management'/de OR } \\
\text { 'productivity'/de OR 'occupational accident'/de }\end{array}$ & 868,721 \\
\hline
\end{tabular}




\begin{tabular}{|c|c|l|c|}
\hline $\begin{array}{c}\text { Safety and } \\
\text { quality } \\
\text { (Free vocabulary) }\end{array}$ & 17 & $\begin{array}{l}\text { ((medical OR diagnostic OR therapeutic OR medication OR } \\
\text { surgical) NEAR/2 error):ti,ab,kw OR (Quality NEAR/2 } \\
\text { Healthcare):ti,ab,kw OR ((Continuous OR total) NEAR/2 ("Quality } \\
\text { Management")):ti,ab,kw OR "hospital accidents":ti,ab,kw OR "Six } \\
\text { Sigma\$":ti,ab,kw }\end{array}$ & 19,013 \\
\hline $\begin{array}{c}\text { Safety and } \\
\text { quality } \\
\text { (combined) }\end{array}$ & 18 & $\# 16$ OR \#17 & 875,097 \\
\hline $\begin{array}{c}\text { Characteristics of } \\
\text { Staff } \\
\text { (Controlled } \\
\text { vocabulary) }\end{array}$ & 19 & $\begin{array}{l}\text { 'job satisfaction'/de OR 'personnel management'/de OR } \\
\text { 'absenteeism'/de OR 'presenteeism'/de OR 'shift work'/exp OR } \\
\text { 'working time'/de OR 'workload'/de }\end{array}$ & 152,737 \\
\hline $\begin{array}{c}\text { Characteristics of } \\
\text { Staff }\end{array}$ & 20 & $\begin{array}{l}\text { ((Job OR Work OR physician\$ OR nurs* OR "allied health\$") } \\
\text { NEAR/2 satisfaction):ti,ab,kw OR ((staff OR Personnel OR } \\
\text { employee) NEAR/2 (Loyalty OR turnover OR rentention)):ti,ab,kw } \\
\text { OR ((Night OR Rotating) NEAR/2 Shift):ti,ab,kw OR } \\
\text { Absenteeism:ti,ab,kw OR Presenteeism:ti,ab,kw OR } \\
\text { (Free vocabulary) }\end{array}$ & 73,538 \\
\hline $\begin{array}{c}\text { Overtime:ti,ab,kw OR workload:ti,ab,kw } \\
\begin{array}{c}\text { Characteristics of } \\
\text { Staff } \\
\text { (combined) }\end{array}\end{array}$ & 21 & \#19 OR \#20 & 184,168 \\
\hline $\begin{array}{c}\text { Combination of } \\
\text { concepts }\end{array}$ & 22 & \#3 AND (\#6 OR \#9 OR \#12 OR \#15 OR \#18 OR \#21) & 20,144 \\
\hline $\begin{array}{c}\text { Embase results } \\
\text { only }\end{array}$ & 23 & \#22 AND [embase]/lim NOT ([embase]/lim AND [medline]/lim) & 7,111 \\
\hline
\end{tabular}

\section{ABI/Inform}

Date of the search: 16-01-2021

Database limit: Limit results to academic publications

\begin{tabular}{|c|c|l|c|}
\hline Concepts & $\#$ & Search strategy & Results \\
\hline $\begin{array}{c}\text { Healthcare } \\
\text { pathway } \\
\text { (Controlled } \\
\text { vocabulary) }\end{array}$ & 1 & SU("Patient care planning") & 465 \\
\hline $\begin{array}{c}\text { Healthcare } \\
\text { pathway (Free } \\
\text { vocabulary) }\end{array}$ & 2 & $\begin{array}{l}\text { TI,AB("workflow management" OR "Healthcare pathway?" OR } \\
\text { "Patient Journey") OR TI,AB((Clinical OR medical OR Healthcare OR } \\
\text { model*) NEAR/3 processes) }\end{array}$ & 25444 \\
\hline $\begin{array}{c}\text { Healthcare } \\
\text { pathway } \\
\text { (Combined) }\end{array}$ & 3 & 1 OR 2 & 25897 \\
\hline $\begin{array}{c}\text { Healthcare access } \\
\text { (Controlled } \\
\text { vocabulary) }\end{array}$ & 4 & SU("Health care access" OR "Medical waiting lists") & 14194 \\
\hline $\begin{array}{c}\text { Healthcare access } \\
\text { (Free vocabulary) }\end{array}$ & 5 & $\begin{array}{l}\text { TI,AB((Health OR "Health Care") NEAR/2 (Access* OR Availab*)) } \\
\text { OR TI,AB(Health NEAR/2 (Equity OR inequit* OR disparities)) OR }\end{array}$ & 17590 \\
\hline $\begin{array}{c}\text { Healthcare access } \\
\text { (combined) }\end{array}$ & 6 & 4 OR 5 & 21608 \\
\hline $\begin{array}{c}\text { Effectiveness } \\
\text { (Controlled } \\
\text { vocabulary) }\end{array}$ & 7 & SU(Mortality OR "Patient Satisfaction") & 443 \\
\hline
\end{tabular}




\begin{tabular}{|c|c|c|c|}
\hline $\begin{array}{l}\text { Effectiveness } \\
\text { (Free vocabulary) }\end{array}$ & 8 & $\begin{array}{l}\text { TI,AB(Patient NEAR/2 (satisfaction OR needs)) OR TI,AB((Hospital } \\
\text { OR Patient OR "30 Day" OR rate) NEAR/2 readmission\$) OR } \\
\text { TI,AB(Mortalit* OR "Death rate") }\end{array}$ & 33009 \\
\hline $\begin{array}{l}\text { Effectiveness } \\
\text { (combined) }\end{array}$ & 9 & 7 OR 8 & 43291 \\
\hline $\begin{array}{l}\text { Efficiency as } \\
\text { productivity } \\
\text { (Controlled } \\
\text { vocabulary) }\end{array}$ & 10 & SU("Time management" OR "Medical referrals") & 5798 \\
\hline $\begin{array}{l}\text { Efficiency as } \\
\text { productivity } \\
\text { (Free vocabulary) }\end{array}$ & 11 & $\begin{array}{l}\mathrm{TI}, \mathrm{AB}((\text { operat* OR surgery OR surgical) NEAR/2 (time? OR duration } \\
\text { OR length)) OR TI,AB((Treatment? OR therapy) NEAR/2 Delay*) OR } \\
\text { TI,AB("Bed Occupancy" OR "Time-to-Treatment" OR "patient } \\
\text { referral") }\end{array}$ & 8704 \\
\hline $\begin{array}{l}\text { Efficiency as } \\
\text { productivity } \\
\text { (combined) }\end{array}$ & 12 & 10 OR 11 & 14465 \\
\hline $\begin{array}{l}\text { Efficiency as } \\
\text { economic } \\
\text { (Controlled } \\
\text { vocabulary) }\end{array}$ & 13 & $\begin{array}{l}\text { SU(Costs OR "Benefit cost analysis" OR "Cost analysis" OR "Health } \\
\text { care expenditures" OR "Hospital costs" OR "Cost control") }\end{array}$ & 489564 \\
\hline $\begin{array}{l}\text { Efficiency as } \\
\text { economic } \\
\text { (Free vocabulary) }\end{array}$ & 14 & $\mathrm{TI}, \mathrm{AB}\left(\right.$ Cost* $\left.^{*}\right)$ & 1062839 \\
\hline $\begin{array}{l}\text { Efficiency as } \\
\text { economic } \\
\text { (combined) }\end{array}$ & 15 & 13 OR 14 & 1308330 \\
\hline $\begin{array}{l}\text { Safety and quality } \\
\text { (Controlled } \\
\text { vocabulary) }\end{array}$ & 16 & $\begin{array}{l}\text { SU("Quality control" OR "Quality of care" OR "Total quality" OR } \\
\text { Efficiency OR "Medical errors" OR "Occupational accidents") }\end{array}$ & 162388 \\
\hline $\begin{array}{l}\text { Safety and quality } \\
\text { (Free vocabulary) }\end{array}$ & 17 & $\begin{array}{l}\text { TI,AB((medical OR diagnostic OR therapeutic OR medication OR } \\
\text { surgical) NEAR/2 error) OR TI,AB(Quality NEAR/2 Healthcare) OR } \\
\text { TI,AB((Continuous OR total) NEAR/2 ("Quality Management")) OR } \\
\text { TI,AB("hospital accidents" OR "Six Sigma\$") }\end{array}$ & 15577 \\
\hline $\begin{array}{l}\text { Safety and quality } \\
\text { (combined) }\end{array}$ & 18 & 16 OR 17 & 168035 \\
\hline $\begin{array}{l}\text { Characteristics of } \\
\text { Staff } \\
\text { (Controlled } \\
\text { vocabulary) }\end{array}$ & 19 & $\begin{array}{l}\text { SU("Job satisfaction" OR "Employee turnover" OR Workloads OR } \\
\text { Absenteeism OR "Shift work" OR Overtime) }\end{array}$ & 45347 \\
\hline $\begin{array}{l}\text { Characteristics of } \\
\text { Staff } \\
\text { (Free vocabulary) }\end{array}$ & 20 & $\begin{array}{l}\text { TI,AB((Job OR Work OR physician? OR nurs* OR "allied health?") } \\
\text { NEAR/2 satisfaction) OR TI,AB((staff OR Personnel OR employee) } \\
\text { NEAR/2 (Loyalty OR turnover OR rentention)) OR TI,AB((Night OR } \\
\text { Rotating) NEAR/2 Shift) OR TI,AB(Absenteeism OR Presenteeism } \\
\text { OR overtime OR workload) }\end{array}$ & 48335 \\
\hline $\begin{array}{l}\text { Characteristics of } \\
\text { Staff } \\
\text { (combined) }\end{array}$ & 21 & 19 OR 20 & 72938 \\
\hline $\begin{array}{l}\text { Combination of } \\
\text { concepts }\end{array}$ & 22 & 3 AND (6 OR 9 OR 12 OR 15 OR 18 OR 21) & 5633 \\
\hline
\end{tabular}




\begin{tabular}{|c|l|l|l|}
\hline $\begin{array}{c}\text { Limit results to } \\
\text { academic } \\
\text { publications }\end{array}$ & 23 & n/a & 3927 \\
\hline
\end{tabular}

